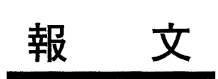

\title{
二本鎖型カチオン界面活性剤の親水性表面への吸着形態
}

\author{
中村 和吉 ${ }^{* 1} \cdot$ 藤原 夏美*1 $・$ 國枝 博信 ${ }^{* 2}$ \\ *1 新潟大学教育学部生活科学教育 (テ950-21 新潟市五十嵐二の町 8050) \\ $* 2$ 横浜国立大学大学院工学研究科人工環境システム学専攻（テ240 横浜市保土ケ谷区常盤台 79-5)
}

\section{Adsorption of Double-chain Cationic Surfactant on Hydrophilic Surface}

\author{
Kazuyoshi NAKAmURA*1, Natsumi FuJiwarA*1, and Hironobu KuniedA*2 \\ *1 Department of Living Science, Faculty of Education, Niigata University \\ (8050 Igarashi-Ninocho, Niigata-shi, $\mathbf{\text { T}} 950-21$ ) \\ *2 Division of Artificial Environments Systems, Graduate School of Engineering, \\ Yokohama National University (79-5 Tokiwadai, Hodogaya-ku, Yokohama-shi, $\mathbf{7} 240$ )
}

\begin{abstract}
The double-chain cationic surfactant (dioctadecyl dimethyl ammonium chloride; DODAC)is used as a fabric-softener or for hair rinsing. The morphologies of DODAC agregates adsorbed on a hydrophilic surface was investigated by electron and atomic force microscopy.

An aqueous DODAC dispersion was dropped on a hydrophilic nitrocellulose membrane and was observed by transmission electron microscopy by using of negative-staining method. Multilayer vesicles (250 $\mathrm{nm}$ in mean diameter) were adsorbed on the hydrophilic surface. Following ultrasonication, small unilamellar vesicles could be observed on the surface.

The texture and thickness of vesicles on the mica surface was measured by an atomic force electron microscopy. The thickness of ultrasonicated vesicles after drying was $4 \mathrm{~nm}$. Interior water of vesicle is eleminated by drying, thus causing the closed-shell structure to collapse, and this may have caused the bilayer to take on an interdigitated structure.

DODAC molecules do not form monolayers on a hydrophilic surface, but are adsorbed as a vesicular state.
\end{abstract}

Key words : adsorption, cationic surfactant, fabric softener, atomic force microscope

\section{1 緒 言}

界面活性剂を用いた固体表面の改質の例として, 織維 製品の柔軟仕上げや, ヘアリンスのくし(櫛)通り性向上 などが知られている(1),2)。これらはいずれも主成分の カチオン界面活性剤が, 固/気界面に吸着して発現する 潤滑作用を利用した製品である。これら製品の主剤に使 用されているカチオン界面活性剤は, 長鎖了ルキル第四 級アンモニウム塩で, とくにジオクタデシルジメチルア ンモニウムクロリド (DODAC) が使用されている。

現在, この二本鎖型カチオン界面活性剤の親水性表面 への吸着機構については, 正の電荷をもつ界面活性剂分 子と, 水中で負の電荷を帯びた表面との間で相互作用 し, 単分子吸着すると考えられている2) 4)。しかし, この場合親油性鎖が水中に露出するため, 熱力学的に不 連絡者 : 中村和吉
利であり，自発的に進行する過程とは考えにくい。一 方，極性をもたない非イオン界面活性剤においても，親 水性表面への吸着・吸着状態に関する報告が行われるよ うになってきている5),6)。それによると，界面活性剂 は親水性表面へ単分子上に吸着しているのではなく, ミ セルが吸着した状態をとっている。DODAC は水中で の単分散飽和溶解濃度は極めて低く, 長鎖親油基を水中 に露出したままで単分子状に吸着するとは考えにくい 7),8。本研究は, この DODAC 分子の親水性固体表面 への吸着現象を透過型電子顕微鏡, 原子間力顕微鏡を用 いて直接観察を行い, 従来の単分子吸着モデルとは異な る結果を得たので報告する。

\section{2 実験}

\section{$2 \cdot 1$ 試 薬}

DODAC は, 東京化成工業(株)製の特級品を用い 
た。リンタングステン酸は, 和光純薬工業(株)製を用い た。いずれの試薬も精製せずにそのまま使用した。

\section{$2 \cdot 2$ ベシクル調製}

所定量の DODAC を $50 \mathrm{~mL}$ バイアルにとり，この 中に少量のエタノールを加えて溶解した後, これを減圧 乾固させてバイアル内に DODAC の薄膜をつくった。 ここに DODAC 濃度が $1.0 \mathrm{wt} \%$ となるように蒸留水を 加え, $40 \pm 1^{\circ} \mathrm{C}$ に設定した定温器内で $16 \mathrm{~h}$ 静置し, DODACを䐍潤させた。

この分散液をボルテックスミキサーで振とうした後, 超音波処理を行った。超音波照射には，島津製作所製の USP-50を用いた。出力は $40 \mathrm{~W}$ で水浴で冷却を行いつ つ $10 \mathrm{~min}$ 照射を行った ${ }^{9), 10) 。 ~}$

\section{$2 \cdot 3$ 透過型電子顕微鏡観察}

銅グリッドにニトロセルロースの支持膜を張り，炭素 膜による補強を行った後,グロー放電によって親水化処 理を行った。放電により䨌囲気中の酸素がオゾンへと変 化し，その酸化作用により炭素膜表面を親水化する。膜 厚の合計は $0.5 \sim 1.0 \mu \mathrm{m}$ に設定した。次に，グリッド 上に所定濃度の DODAC 分散液を滴下し, 続いて 2.0 wt \% リンタングステン酸水溶液を滴下し，ネガティブ 染色を施した ${ }^{11), 12)}$ 。この試料を透過型電子顕微鏡 (JEOL-JEM-2000 FX II )で観察した。加速電圧は 160 $\mathrm{kV}$ に設定した。

\section{$2 \cdot 4$ 表面元素分析}

表面元素分析には, X 線マイクロアナライザー LinkQX 2000 JI を用い, 透過型電子顕微鏡観察で使用した 試料表面の吸着物質について測定を行った。この分析法 は試料表面に加速電子を照射し, 試料表面に存在する元

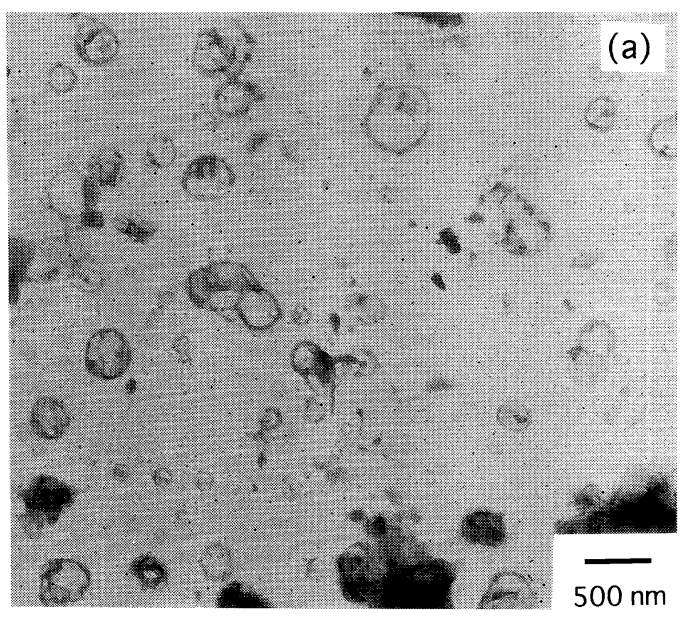

素から放出される特性 $\mathrm{X}$ 線のエネルギーによって, 元 素を同定することができる ${ }^{13)}$ 。本装置は透過型電子顕 微鏡に付設されており, 検鏡下での微小表面分析が可能 な機種である。加速電圧は $160 \mathrm{kV}$, 電子ビーム直径は $200 \mathrm{~nm}$ に設定した。

\section{$2 \cdot 5$ 原子間力顕微鏡観察}

原子間力顕微鏡観察 (AFM) はセイコー電子工業(株) 製の走査型プローブ顕微鏡 SPI-3700 を用い, 試料表面 の形状観察および厚さの測定を行った。所定濃度のDODAC 分散液をマイカ基板上に滴下し, 窒素ガスで乾燥 したものを観察に供した ${ }^{14)}$ 。

\section{3 結果と考察}

\section{3・1 親水性表面に吸着した DODAC の形態観察}

國枝, 篠田らが報告した水-DODAC 系の状態観察に よれば, DODAC の水に対する溶解性はきわめて低 く, 水中ではラメラ液晶が共存した二相系を形成してい る ${ }^{15)}$ 。DODAC が親水化処理した炭素膜表面に吸着し ている状態を, ネガティブ染色法による透過型電子顕微 鏡で観察した (Fig. 1)。

この方法は，水中に分散している DODAC の直接観 察ではなく, 親水性表面に吸着・乾燥した状態を観察し ているものである。柔軟仕上げ剤等の製品として機能し ているのは, この状態である。Fig. 1(a) より, Vortex ミキサーで調製した試料は, 直径 $100 \mathrm{~nm}$ 以上の円 形物体が多数存在した。この染色条件では直径 $100 \mathrm{~nm}$ 以下の粒子は染色が不充分になり, コントラストの低い 像となって判別を困難にしている。判別できた粒子像か ら平均値を算出すると, 平均粒子直径は $241 \pm 50 \mathrm{~nm}$ と

Fig. 1 Microphotograph of 1.0 wt\% DODAC Dispersion by Using of Negative Staining Method. The sample was prepared by (a) vortex mixing, and (b) ultrasonication. And was put on the hydrophilized supporting film by glow discharge. Very small dots are the precipitated Wolfrum particles as a contamination. 
多分散であり，700 nm を越えるものも見られた。円形 物体像には，ふちどり様の染色パターンが多数観察でき た。これはリン脂質が水中で形成する多重層ベシクルと 同様のパターンであり，本研究で得られた円形物体像も

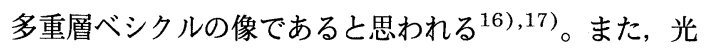
学顕微鏡（微分干涉顕微鏡）にてこの分散を観察したと ころ, 直径 $1 \mu \mathrm{m}$ 以下の粒子がブラウン運動をしている のが確認できた。よって本研究で得られた電子顕微鏡像 は，DODAC からなるベシクルが乾燥した状態で得ら れているものであり, 試料調製あるいは検鏡時の電子線 照射にともなうアーティファクトではないことがわかっ た。

一方, 超音波処理を行った Fig. 1(b) では, 平均粒 子直径は $44 \pm 5 \mathrm{~nm}$ と単分散性が高くなり, 直径 100 $\mathrm{nm}$ を越える粒子は見られなくなった。超音波を照射す ることによってベシクルの粒径は小さくなり，一枚膜の ベシクルが形成していると思われる。

また, Fig. 1(a)で形態観察を行った試料中の, 直径 $300 \mathrm{~nm}$ 以上のベシクルに対して表面元素分析を行っ た。分析結果を Fig. 2 に示す。

この図より, 試料中のベシクル表面から塩素と染色剂の タングステン由来の特性 X 線が放出していることがわ かる。共存するリン, 炭素, 窒素, 酸素は軽元素のため $\mathrm{X}$ 線シグナル強度が低く, かつタングステン由来のシ グナルと重なってしまい同定できなかった。また, ベシ クルの吸着していない領域で同様の分析を行ったとこ ろ，塩素のシグナルは検出されなかった。形態観察の際 に使用した試料中において塩素が含まれる物質は DO$\mathrm{DAC}$ 分子のみであるから, 透過型電子顕微鏡で観察さ れた円形の吸着物体は, DODAC 分子が多数集合した ベシクルであることがあらためて確認できた。

\section{$3 \cdot 2$ 吸着状態での構造推定}

透過型電子顕微鏡像は, 試料の厚さ方向の情報に乏し い。親水性表面に吸着したベシクルの乾燥時での状態
を, AFM によって試料表面の凹凸状態を観察した (Fig. 3, 4)。

これらの像は水中に分散していたベシクルが, 親水性 表面を有するマイカと水の固/液界面に吸着し, 乾燥と ともに水が大気と置換した状態を観察したものである。 マイカを構成する二酸化ケイ素の等電点は $2 \sim 3$ である ので ${ }^{18)}, \mathrm{DODAC}$ の $1.0 \mathrm{wt} \%$ 溶液では，表面のシラ ノール基は解離し負電荷を帯びている。Fig. 3(a) は直 径 $100 \mathrm{~nm}$ 以上の多重層型と思われるベシクルが多数存 在し, Fig. 3(b) は直径 $70 \mathrm{~nm}$ 以下の一枚膜型と思わ れるベシクルがマイカの表面に吸着している。いずれも 形状は円盤状・半球状であり, 不定形は像は得られな かった。江角らはシリカ微粒子上に吸着した DODAC からなるベシクルが, 偏平状薄膜と変形していると予想 した ${ }^{19)}$ 。本研究の結果は彼らの予想を支持するものと なった。

Fig. 4 は, Fig. 3 中に示した直線上で AFM の探針 を走査して, 試料表面の凹凸状態を測定したものであ る。その結果, 多重層ベシクルが形成していると思われ る Fig. 4(a) は, 断面がなだらかな半球状となり, 厚さ は $20 \mathrm{~nm}$ 以上となった。一方, 一枚膜型べシクルが形 成していると思われる Fig. 4(b) は, 断面の形状は長 方形型であり, 吸着層の厚さは $4.0 \mathrm{~nm}$ だった。また, Fig. 4(b) の断面プロファイルにおいて, バックグラウ ンドのノイズ高さが $0.4 \mathrm{~nm}$ になる箇所がある。これは 類似分子 (hexadecyl trimethyl ammonium bromide) の親水基一つ分の大きさに相当する。これを気 体膜状に吸着して横倒しとなった DODAC 分子とみな すか否かは, さらなる検証が必要である。しかし，これ まで柔軟仕上げ剤などのモデルとして知られているよう な, 倒立した単分子膜は形成していないことが明らかと なった。

これらの結果より以下のことが考えられる(Fig. 5)。 一般に脂質二分子膜は水のバリヤー能を示さず, 水の透

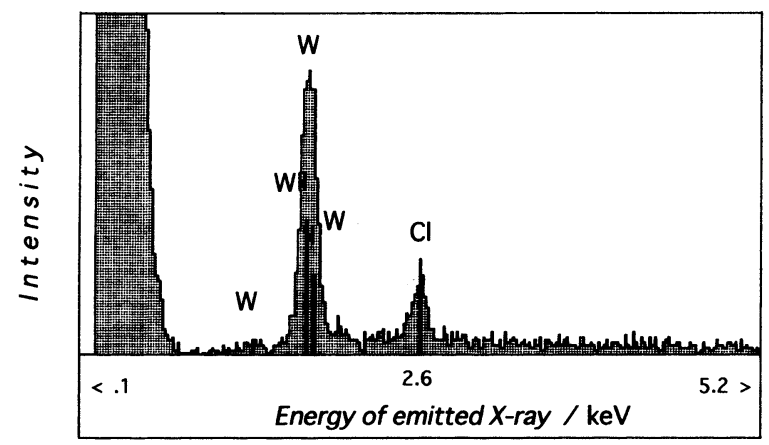

Fig. 2 Electron Probe Micro-analysis Spectrum for $1.0 \mathrm{wt} \%$ DODAC Dispersion. The sample is the same as Fig. 1(a). 

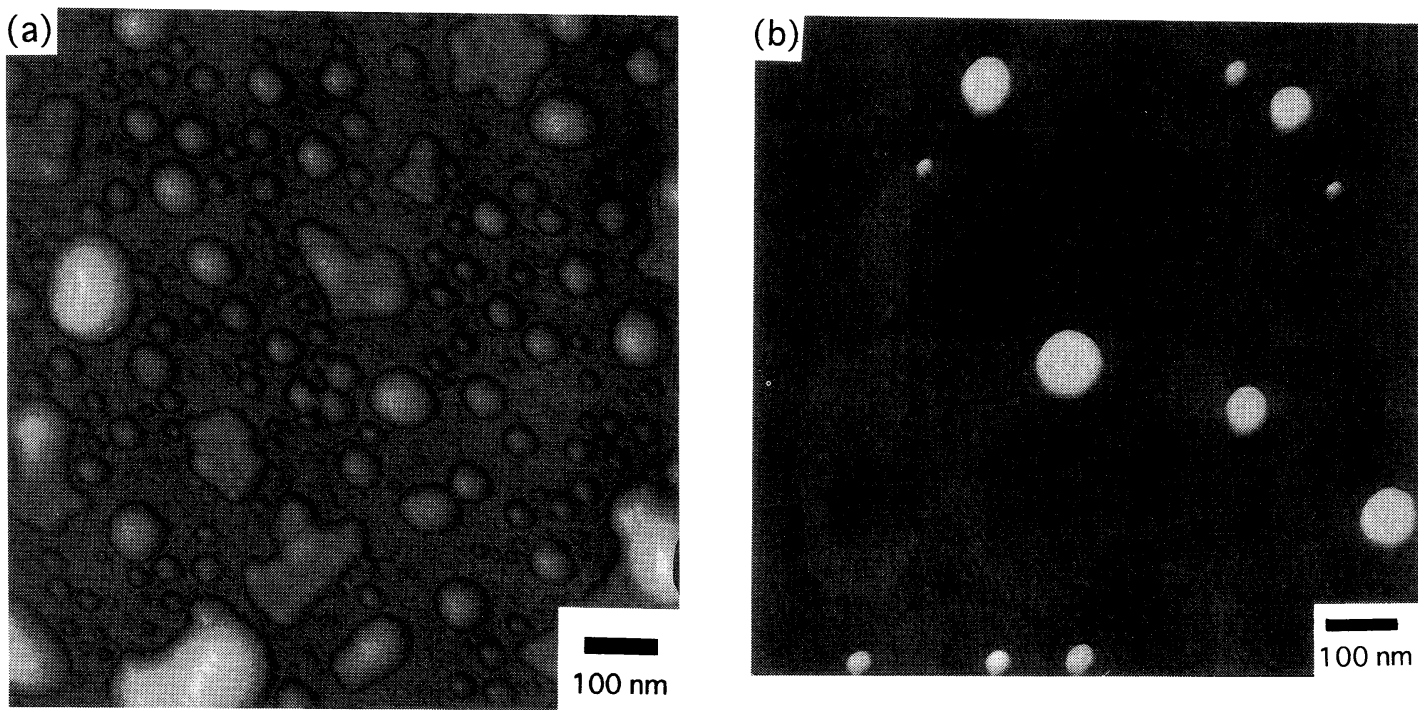

Fig. 3 AFM Micro-image for Vesicles of DODAC on Mica Surface.

The sample was prepared by (a) vortex mixing and (b) ultrasonication.
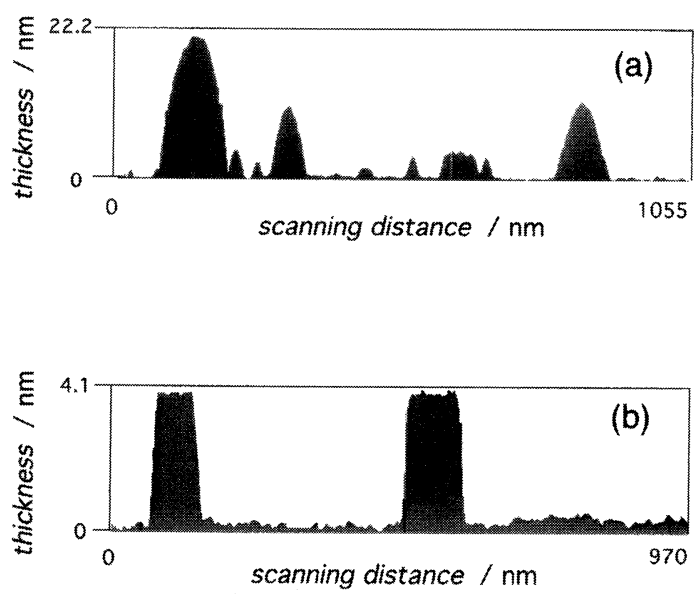

Fig. 4 AFM Scanning Profile for $\mathrm{Z}$-axis along the Line in Fig. 3.

The sample was prepared by (a) vortex mixing, and (b) ultrasonication.

過性が高いと報告されている20)。つまり水中で形成し た DODAC のベシクルは, 乾燥することにより膜内か ら水が外部に移動する。水が抜けた一枚膜ベシクルはつ ぶれて円盤状になり，このときの断面形状は長方形型を とる。脂質二分子膜の一枚の厚さは $3 \sim 5 \mathrm{~nm}$ であるこ とから ${ }^{9), 10)}$, 親水性表面に吸着したベシクルは, 内水 相の移動にともないつぶれていき，二枚の二分子膜が重 なった円盤を形成する。さらに interdigitate 構造に転 移して，厚みを減少させていると考えられる21),22)。 通常の二分子膜構造から interdigitate 構造へと転移

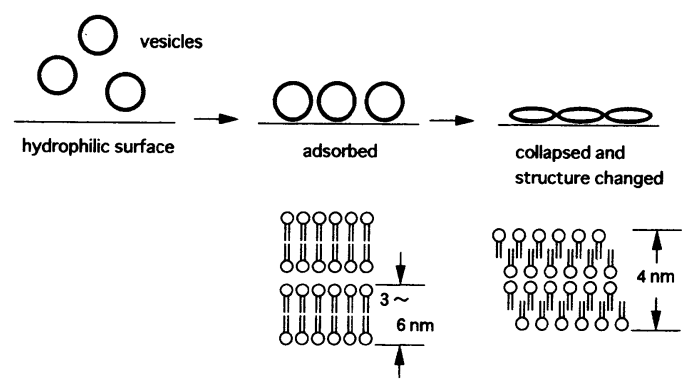

Fig. 5 Schematic Illustration of an Adsorption of the Double-chain Cationic Surfactants on Hydrophilic Surface.

The vesicular bilayer changes into an interdigitate membrane.

する機構については, 明らかとなっていない。親水性表 面という場のもとでは, 複数の界面活性剂分子が水を介 して生じる相互作用や疎水性相互作用の他に, 固体表面 との間での相互作用も支配的因子となる。これらが複雑 に作用するため，詳細な理解を困難にしている。

また，得られた膜厚は二分子膜一枚分に相当すること から，ベシクルが破裂して一枚膜状に吸着している可能 性もある。しかし, AFM でのベシクル像は不規則な形 状を示さず真円に近い形状をしており，ベシクルの破裂

・破壊を伴っていないことの証左となっている。

本研究によって得られた知見は, 二本鎖型カチオン界 面活性剂の織維・毛髪表面への吸着挙動が, 今日までに 提案されている単分子層吸着モデルとは異なることを意 味する。今後は, 緎維製品の柔軟仕上げ効果・はっ水性 
付与の機構について, ベシクル吸着モデルによる系統的 な検討を加えていきたい。

\section{謝 辞}

AFM 観察においてセイコー電子工業(株)科学機器事 業部, 透過型電子顕微鏡観察において横浜国大電子顕微 鏡室の島田保昌氏のご協力をいただきました。ここに記 して謝意を表します。

（受付： 1997 年 4 月 7 日，受理：1997 年 9 月 4 日）

\section{文献}

1) 藤原康晴, 前川輝彦, 村岡雍一郎, 横川公子, “衣生活 論”, 化学同人, (1996), p. 77.

2) 花王生活科学研究所, “清潔な暮らしの科学 [生活 編?”, 花王生活科学研究所 (1993).

3）妹尾 学, 辻井 薰, “界面活性の化学と応用”, 大日本 园書 (1995), p. 149.

4） 日本化学会編, “コロイド科学 III 生体コロイドおよび コロイドの応用”，東京化学同人 (1996), p. 230.

5) F. Tiberg, M. Langren, Langmuir, 9, 927 (1993).

6) F. Tiberg, B. Jönsson, J-a. Tang, B. Lindman, Langmuir, 10, 2294 (1994).

7) J.N, Israelachvili, "Intermolecular and Surface Forces", Academic Press (1985).

8) C. Tanford, "The hydrophobic effect", John Wiley \& Sons Inc. (1980).

9）野島庄七, 砂本順三, 井上圭三, “リポソーム”, 南江
堂, (1988).

10) M.N. Jones, D. Chapman, “Micelles, Monolayers, and Biomembranes", Wiley-Liss Inc. (1995), Chap. 2, 5

11) 水平敏知, “医学・生物学領域の電子顕微鏡操作マニュ アル”, 講談社 (1988).

12）野々村祜昭, “電子顕微鏡”, 日本電子顕微鏡学会関東支 部, 丸善 (1986).

13) 日本化学会編, “コロイド科学 IV コロイド科学実験 法”東京化学同人 (1996) p. 31.

14）日本化学会編, “コロイド科学 IV コロイド科学実験 法”東京化学同人 (1996) p. 33.

15) H. Kunieda., K. Shinoda., J. Phys. Chem., 82, 1710 (1978).

16) T. Kunitake, Y. Okahata, J. Am. Chem. Soc., 99, 3890 (1977).

17) T. Kunitake, N. Nakashima, S. Hayashida, K. Yonemori, Chem. Lett., 1979, 1413.

18）古澤邦夫, “ゼーター電位”, サイエンティスト社 (1995), p. 114.

19) K. Esumi, A. Sugimura, T. Yamada, K. Meguro, Colloid \& Surfaces, 62, 249 (1992).

20) B. Albert, D. Bray, J. Lewis, M. Raff, K. Roberts, J.D. Watson, "Moleculat Biology of the Cell" Garland Publishing Inc. (1983), p. 287.

21) D.A. Wilkinson, D.A. Tirrell, A.B. Turek, T.J. McIntosh, Biochim. Biophys. Acta, 905, 447(1987).

22) J.A. Scamehorn, R.S. Schechter, W.H. Wade, $J$. Colloid Interface Sci., 85, 463 (1982). 


\title{
[報文］「二本鎖型カチオン界面活性剂の親水性表面 への吸着形態
}

\author{
中村 和吉*1 $・$ 藤原 夏美*1 $・$ 國枝 博信*2 \\ *1 新潟大学教育学部生活科学教育 ( $\bar{\top} 950-21$ 新潟市五十嵐二の町 8050 ) \\ $* 2$ 横浜国立大学大学院工学研究科人工環境システム学専攻（干240 横浜市保土ケ谷区常艋台 79-5)
}

二本鎖型カチオン界面活性㓮（ジオクタデシルジメチルアンモニウムクロリド；DODAC）は，柔軟仕上げ剤や ヘアリンスの主剤として用いられている。その親水性表面への吸着状態を電子顕微鏡, 原子間力顕微鏡により観察 した。

親水化処理をほどこしたニトロセルロース膜にDODAC の水中分散液を滴下し，ネガティブ染色法を用いて電 子顕微鏡観察を行った。超音波処理を行わない試料に関しては, 膜上には平均直径 $250 \mathrm{~nm}$ の多重層ベシクルが膜 上に吸着していた。超音波処理を施した試料は, 一枚膜型ベシクルを形成する。

マイカ基板上に DODAC 分散液を滴下して，原子間力影微鏡により吸着したベシクルの形態および厚さを測定 した。超音波処理を行ったベシクルは, 乾燥後の厚さが $4 \mathrm{~nm}$ となった。これはベシクルの内水相が乾燥とともに 外部へ流出し，閉款構造がつぶれて，さらに二分子膜が指組構造をとっていると考えられる。

これらの結果より DODAC は単分子の状態で吸着するのではなくべシクルの状態で親水性表面に吸着している ことが明らかとなった。

（連絡者 : 中村和吉）Vol. 46, No. 12, 1461 (1997)

\section{[報文 $] \quad$ 液体ガルシニアエキス及び水溶性ガルシニア パウダーの体重変化に及ぼす影響 一体脂肪蓄積予防素材としての可能性一}

\author{
澤田 玄道・富＼cjkstart裕孝・田村 幸一・阿武 尚彦 \\ 日本新薬株式会社食品開発研究所（敄601 京都市南区西大路通八条下ル）
}

ガルシニアは体重の減少に効果があるとして知られているスパイスである。今日，カルシウム型のガルシニア抽 出エキスを含む多くの製品が上市されているが, 有効成分の $(-)$ ヒドロキシクエン酸 $(\mathrm{HCA})$ はおそらくカルシウ ム塩として存在している。カルシウム型のパウダーは安定性に優れているが, 水に不溶性であるので食品への使用 が限られている。したがって, 水溶性のガルシニアエキスが望ましいが, HCA のラクトン型が含まれるようにな る。HCA のラクトン型は脂肪合成系の鍵酵素である ATP-クエン酸リアーゼに対する阻害活性が試験管内では極 めて低いので, ラクトン型を大量に含む水溶性ガルシニアエキスの体重減少への効果は低いものと思える。しかし ながら，ラクトン型が生体内では活性型になる可能性を示した報告がある。そこで, HCA のラクトン型を含む水 溶性ガルシニアパウダーと, 液体ガルシニアエキスを調製し, カルシウム型のガルシニアエキスと比較するととも にラット及びヒトでの体重の変化に及ぼすそれらの効果を検討した。

その結果，飼料之同時に投与する条件では，水溶性パウダーの方がカルシウム型ガルシニアパウダーより，ラッ 卜の体重の増加抑制には効果のあることが示唆された。また, 水溶性ガルシニアパウダー, 液体ガルシニアエキス のいずれも，脂肪の蓄積を抑制することにより，ヒトの体重減少に有効であることが示唆された。

（連絡者：澤田玄道) Vol. 46, No. 12, 1467 (1997) 